Brit. J. industr. Med., 1953, 10, 269.

\title{
AGE AND WORK* \\ A STUDY OF 489 MEN IN HEAVY INDUSTRY
}

BY

\section{M. RICHARDSON}

From the Department of Public Health and Social Medicine, University of Aberdeen

(RECEIVED FOR PUBLICATION JULY 15, 1953)

Of the numerous expressions of future demographic trends in Britain, none is more starkly realistic than the calculation of the Royal Commission on Population (1949) that :

"The cost to the Exchequer of retirement pensions, making no allowance for any future fall in mortality, is estimated (at pension rates current in 1948) to increase from $£ 238$ millions in 1948 to $£ 501$ millions in $1978 \%$.

An extension of working life beyond the present conventional retiring age would both reduce national expenditure and increase national income, but if indeed "occupation is the best medicine" it would also achieve an immeasurable increase in health, happiness, and efficiency for old folk themselves.

Much has been said and written on the employment of old people. Reduced to its elements the problem is how to provide suitable work for those who are fit, willing and have, or can acquire, the necessary skills. It is important to remember that this problem does not arise only at or after the age of 65 years ; there is evidence that it begins some years earlier. Table 1 shows the percentage unemployment by age groups in June, 1950 (Ministry of Labour Gazette, June, 1951).

TABLE 1

AGE AND UNEMPLOYMENT IN BRITISH MALES, JUNE 1950

\begin{tabular}{c|c|c|c}
\hline $\begin{array}{c}\text { Age } \\
\text { Group }\end{array}$ & $\begin{array}{c}\text { Estimated } \\
\text { Total No. of } \\
\text { Employees }\end{array}$ & $\begin{array}{c}\text { Nos. Registered } \\
\text { as Wholly } \\
\text { Unemployed }\end{array}$ & $\begin{array}{c}\% \\
\text { Unemployed }\end{array}$ \\
\hline $15-20$ & $1,290,000$ & 15,780 & $1 \cdot 2$ \\
\hline $21-40$ & $6,226,000$ & 67,635 & $1 \cdot 1$ \\
\hline $41-50$ & $3,018,000$ & 38,208 & $1 \cdot 3$ \\
\hline $51-55$ & $1,117,000$ & 22,503 & $2 \cdot 0$ \\
\hline $56-64$ & $1,563,000$ & 45,839 & $2 \cdot 9$ \\
\hline Total & $13,214,000$ & 189,965 & $1 \cdot 4$ \\
\hline
\end{tabular}

*This work was done in 1951 during the tenure of a full-time gran from the Medical Research Council.
The significant rise from the 40 s onwards in the proportion of unemployed indicates that older people who have given up one job find increasing difficulty in obtaining another. From the social survey by Thomas and Osborne (1950) came the finding that the average age at retirement from full-time work of a fairly representative sample of men age 55 to 74 was 62 years. It may be concluded that the retention of older people in work is not solely a matter for attention at age 65 .

\section{Suitable Work}

If older people are to be retained in or regained by industry their efficient employment depends upon the application of knowledge regarding what constitutes suitable work for them. The search for a definition of work appropriate to older people as a group consists basically of the discovery of changes with age in psycho-physiological function. Since the measurement of any human function is a measurement of range, such a definition must necessarily be a general one within which the problem of the suitability for work in a given individual will be solved by individual assessment.

In respect of age, this individual variation is of particular importance. Both experimental (Welford, 1951) and field research (Sheldon, 1948) have shown that with increase in age the average level of performance or activity tends to fall and the scatter round that average tends to increase. If this fundamental fact is ignored there is a danger that suitable work for older people may be too tightly defined in terms of the average with inevitable detriment to those individuals whose capacities lie well above or below that average.

\section{Age and Skill}

The experimental and field studies of the Nuffield Unit for Research into Ageing (Welford, 1951) have shown that as age increases there is a fall in 
the ability, and perhaps also the inclination, to do work demanding high pressure for speed. It would seem that work in which piece-rate payments, or pacing by a machine or conveyor belt, force the worker to maintain rapid rates of performance is unsuitable for the majority of older people who prefer, indeed require, jobs where the rate of working is at least to some extent under their own control.

The second important indication reported by Welford is that skill is more easily acquired by younger people but once acquired is usually well maintained in the upper age groups. The industrial and experimental studies taken together indicate that learning difficulties on some types of operation appear as early as the 30 s and that a major difficulty for older people lies in the comprehension of situations which are novel or confusing in " display".

The practical implications of these findings are neither simple nor straightforward, first because every older individual does not exhibit the changes mentioned, and secondly because even those who do will not necessarily be employed on high speed work. From the industrial standpoint therefore the problem becomes one of detecting those individuals who in middle life show signs of strain, and either modifying the job to which they are accustomed or transferring them to new jobs which offer a lower tempo of work. Of these alternatives the first is the more desirable in view of the demonstration that older people tend to have more difficulty in mastering new skills.

Industrial Skill.-It is commonly believed that the lot of the older unskilled man is much less happy than that of his more skilled contemporary. Implicit in that view is the suggestion that by increasing the proportion of skilled young people the future problems of age and work will be correspondingly smaller. From a general socioeconomic standpoint the need for more skilled workers is undoubted, but it is by no means certain that the problem of suitable work for older people would be solved by an all-round increase in the number of skilled workers.

In the social survey by Thomas and Osborne (1950) a comparison was made between the occupations of a sample of men aged 55-74 years and those of a sample of the male population aged 18 years and over. From the definitions provided, it can be assumed that " manipulative workers" correspond with the designation "skilled" and "opera-
TABLE 2

PROPORTIONAL DISTRIBUTION OF OCCUPATIONS IN TWO MALE SAMPLES (Thomas and Osborne, 1950)

\begin{tabular}{|c|c|c|c|c|}
\hline Occupation & & & $\begin{array}{c}\text { Men Aged } \\
55-74 \\
(\%)\end{array}$ & $\begin{array}{c}\text { Men Aged } \\
18 \text { and Over } \\
(\%)\end{array}$ \\
\hline $\begin{array}{l}\text { Professional and technical } \\
\text { Managerial.. } \\
\text { Clerical . } \\
\text { Manipulative (skilled) } \\
\text { Operatives (semiskilled) } \\
\text { Unskilled . . . }\end{array}$ & $\begin{array}{l}\cdots \\
\cdots \\
\cdots \\
\cdots\end{array}$ & $\begin{array}{l}\cdots \\
\cdots \\
\cdots \\
\cdots \\
\cdots\end{array}$ & $\begin{array}{r}5 \\
27 \\
7 \\
14 \\
25 \\
22\end{array}$ & $\begin{array}{r}5 \\
20 \\
5 \\
20 \\
35 \\
15\end{array}$ \\
\hline Size of sample & . & . & $\begin{array}{l}1,274 \\
(100 \%)\end{array}$ & $\begin{array}{l}3,686 \\
(100 \%)\end{array}$ \\
\hline
\end{tabular}

tive" with "semiskilled". The findings are shown in Table 2.

For the higher proportion of older men in managerial posts promotion is the likely explanation. The interesting points are the smaller proportion of older men in the skilled and semiskilled groups and the higher proportion in the unskilled group; these differences suggest that a number of men in the upper age groups have moved to less skilled work. The terms " unskilled", "skilled", and "semiskilled" must include a wide range of jobs and the explanation of this move to unskilled work may lie in the nature of a few selected tasks embraced by them rather than in some feature of skill as a whole, but the figures show the need for caution when relating level of industrial skill to the problem of suitability for work at older ages.

Alongside this observation must be set two further findings from the same social survey. Among the 55-74 age group the incidence of longterm unemployment since age 45 was $26 \%$ in the unskilled compared with $11 \%$ in the skilled group. In this respect the possession of skill was an advantage, but when a sample of employers was asked what weight they would attach to skill when engaging new workers over 45 years of age, it appeared that an older skilled worker had only a slightly better chance of employment than an unskilled worker over that age.

Despite the strong belief that skilled workers encounter fewer problems as age advances, there appear to be grounds for suspecting that they do in fact meet difficulties. The adjective "skilled" however refers only to one aspect of an industrial task ; it is possible that two tasks of similar complexity in skill may require very different amounts of effort for their execution and, should a move off the heavier task be made on grounds of fitness, the change may be mistakenly associated with the skill or vice versa. 


\section{Age and Fitness}

"It must be frankly admitted that so far no reliable standard of measurement of fitness has been evolved. Many attempts have been made to assess this elusive yet recognizable quality. Physical fitness depends on a collection of qualities, psychological as well as physiological, and it is extremely difficult to determine which combination is likely to give the truest index" (Cathcart, Hughes, and Chalmers, 1935).

Despite intensive research the quantitative assessment of fitness is still a complex and controversial problem. A discussion of the validity of the various indices of fitness is outside the scope of this paper, but it is appropriate to note that there appears to be a lack of general agreement on how far the results of the many tests of fitness correlate with general or particular efficiency for real life tasks. The resemblance between the two kinds of work-work performed in a test and in industryis usually slight, especially in regard to duration and distribution of effort; even the simplest manual labour in industry may vary widely in the timing and nature of its demands on the labourer.

No claim is made that the facts here presented are a complete distillate of the extensive research literature on fitness but those which are cited appear to indicate the general trend with age in certain important functions.

Tests of Fitness. - The findings from several investigations into changes with age in muscle strength have been reported (Cathcart and others, 1935 ; Simonson, 1947 ; Cullumbine, Bibile, Wikramanayake, and Watson, 1950). The general trend revealed is a peak in the 20 s and 30 s followed by a gradual decline to about $80 \%$ of peak values in the $50 \mathrm{~s}$ and $60 \mathrm{~s}$. These studies reveal nothing to suggest that older people are unable to do work in which occasional strenuous lifting or gripping is required but such tests do no more than measure an isolated local ability.

A variety of cardio-respiratory indices have been measured by exercise response tests, and from those in which age has been studied as a major variable the general trend is similar (Robinson, 1938 ; Simonson, 1947 ; Shock, 1947 ; Cullumbine and others, 1950 ; Hugh-Jones, 1952). With increasing age the physiological reserves become reduced, the capacity to respond to and recover from exercise is lowered, and the physiological cost of work becomes greater. Fitness as measured by these various indices is therefore reduced but it needs to be stressed that the change as expressed in terms of an age-group average is gradual and that many older people are well above or below that average.
It is permissible to infer from these test results that rest pauses should be more frequent for older people and that they should be allowed a rather lower level of working effort. Such conclusions do not really tell industry any more than it already knows. They do, however, serve to emphasize the urgent need for accurate knowledge of the physical demands of different kinds of industrial work. Until that knowledge is available the relation between fitness for laboratory test-work and real-life work will continue to be uncertain.

Training.-It is well known that training can improve performance on tasks requiring strenuous work. Crowden (1928) and Robinson (1938) have given convincing demonstrations of the economy of energy expenditure which can be achieved by trained practice, and it would seem reasonable to suppose that other things being equal those older men whose lives have mainly been spent on heavy work are likely to be more physically fit for active work than those accustomed to more sedentary occupations.

Lastly it is right that the importance of the individual's place in the group should be reiterated. Since the, placing in suitable work of older people eventually comes down to an individual problem, it is earnestly to be hoped that simple, reliable tests of fitness can be evolved, from the results of which accurate individual guidance can be given to those whose further employment presents difficulty on grounds of fitness.

\section{Age and Motivation}

How much a man is willing to do and interested in doing may obviously vary with age. The scientific study of motivation is only beginning (Bartlett, 1951a) and where facts are few opinions are many. In the industrial world, where much of the work done offers little opportunity for satisfaction, it is perhaps not surprising that many older men show little inclination to work beyond the age at which pensions become payable.

A succession of speculations on the attitude of older people to work can serve no useful purpose, but it would be unfair to omit reference to the widespread belief that older people do in general display in greater measure such virtues as carefulness and responsibility. How valuable these may be to an employer has been described by Richardson (1953).

Although the effects of age on motivation are as yet uncertain, there is no doubt that in real life attitude to work is as essential a factor in the consideration of employment of older people as 
are skill and fitness. Indeed none of these three can be thought of or studied in isolation from the others. The truth of that contention can be exemplified in many industrial jobs ; for example, an ironmoulder paid by piece rates has to perform skilled work at a rapid tempo demanding a high level of energy expenditure. As he comes nearer to the age of 65 his cerebral mechanism controlling skill and/or his physiological mechanism controlling effort may decline and his reduced family commitments may lower his interest in and willingness for his job; should he seek a change of work, it would be difficult to say how far each variable was responsible.

\section{Age and Industry}

It is evident that a definition of suitable work for older people is still very incomplete. Industry has always encountered the problem of age and work, and its solution has varied according to economic circumstances; there are welcome signs that the more enlightened firms are beginning to tackle the problem with a view to adjusting their production to an ageing labour force.

The nature of the problem varies. In many lighter industries the difficulty for older people lies in the realm of skill, whereas in heavier industries decline with age in fitness assumes greater importance. The simple fact that British economic stability rests mainly on its heaviest industriescoal, iron, and steel-makes the necessity for knowledge of the relation between age and heavy work an urgent one.

Heavy Work.-Since there is no clear cut definition of heavy work it is not easy to study its relationship to age. It is often claimed that heavy industry cannot employ many older men but some recent evidence suggests that this is by no means an accurate statement. The Industrial Welfare Society's Report (1950) on 400 of its member firms showed that whereas the number of men over 65 years of age expressed as a proportion of all men employed by these firms was $2.7 \%$, the proportion in two heavy industries-tin and sheet steel-was $4.7 \%$. In a survey of the age distribution of 110,000 men employed by 42 firms in the iron and steel industry Fleming (1952) found that the average proportion of the labour force aged 65 years and over was $4 \%$, with a range from $0.7 \%$ to $11.3 \%$. These observations reveal the need for caution when speaking of the connexion between age and heavy industry.

There is little information on older people and heavy jobs. Belbin and Sewell (1950) studied age distributions on a number of industrial operations included among which were "... operations involving considerable muscular effort in the handling of heavy materials and operations involving a degree of activity which made them regarded as heavy in the factories concerned". They reached the conclusion that many heavy jobs are carried out by older people, especially when time rates are paid or where the effort is intermittent and the speed at which the work is performed can be regulated by the individual. On jobs which required continuous heavy exertion few older men were found and definite evidence was obtained of moves off these jobs between the age of 50 and 60 .

Industrialists, and especially industrial physicians, are familiar with the problems raised by moves off heavy work by older men. The provision of alternative work is often difficult and men may be forced to retire simply because suitable work is not available. If to the effect of age is added some disability the plight of the older workmen is an unhappy one. In a follow-up study of the return to work of male hospital patients aged 50-64 years, Pemberton and Smith (1949) found that those who had been employed in the coal-mining and steel industries had severe difficulty in obtaining work suited to their capacity.

\section{The Present Investigation}

The study here reported was designed to explore the answers to four questions relevant to the relation between age and heavy work: (1) Are older men doing less heavy work than younger men ? (2) At what age do men move to less heavy work? (3) With what factors are these moves associated ? (4) What is the state of health of older men in heavy industry?

The first problem was how to obtain access to the information sought. Personal interview was chosen as the method most likely to yield results of value, and it was therefore necessary to find a group or groups of men which would satisfy several requirements : (1) They should be reasonably concentrated. (2) They should be employed or have been employed in industries where a high proportion of heavy jobs was likely. (3) They should contain a substantial proportion of older men.

For a complete investigation it was necessary to draw samples from employed, unemployed, and retired men in each age-range. The difficulties encountered in the attempt to achieve completeness were so formidable that the last two categories had to be omitted; the study therefore was concentrated on men at work, though it was realized 
that by so doing an uncertain amount of its value would be sacrificed.

Eventually the three stated requirements were met in two iron-foundries and a coal-mine.

The Interviews.-An essential first step was definition of the lower limit of the age-range within which men were to be interviewed. Some of my previous experience as an industrial medical officer suggested that men aged 50 years and over would provide the required data; this limit was also satisfactory in that from the age distributions of both foundries and coal-mine it appeared likely to yield a sufficient number of men for interview in one complete year.

Accordingly only men aged 50 years or more as recorded (at the place of work) on their last birthday were asked to come for interview during working hours.

The scope and content of the interviews were as follows :-

Health.-Questions covered the subjects' past and present health.

Past.-This included the date, duration, and nature of all injuries and illnesses causing absence from work for one month or more at any time.

Present.-To the question, "What is your present state of health?" the actual replies were recorded, thus providing self-assessments of health. The presence of any symptoms or disabilities was noted and whether medical attention was being received.

Job Changes on Health Grounds.-Subjects were questioned concerning any change of job dictated by health.

Occupation.-Again the past and present were covered.

Past.-Each man was asked what kind of work he had done since age 20. The class of work was sought rather than a detailed description of every job ; questions were devised to ascertain the level of skill, physical effort, the duration of each job, and whether and for what reason a move to less heavy work had been made.

Present.-Facts similar to those above were obtained for the job at the time of interview, but special encouragement was given to each man to assess the heaviness of his job and its general suitability in relation to his age.

As soon as possible after the interview a visit was paid to each man's place of work. Observation of the job in progress together with the opinion of workmen and supervisors made it possible to place each job in one of three grades of physical effort.
The Study Material.- The study material was found in two foundries and a coal mine.

Large Foundry.- - In the large foundry a variety of solid fuel cooking and heating stoves was produced in two main stages, by making components in the foundry, and their assembly in the factory.

In both sections of the works much handling of components was necessary and in general the level of physical effort was considerable.

The firm was long established with strong local traditions ; it lay on the edge of an industrial area in which foundries, brick works. and coal-mines were the chief places of employment. A total of 879 male non-staff weekly wage-earners was employed, and of these 244 (28\%) were aged 50 years and over; 223 were interviewed the other 21 being accounted for as follows :

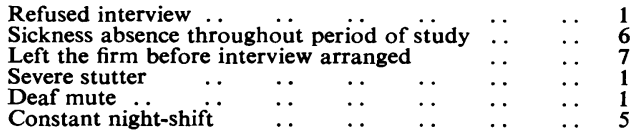

The managerial policy for older non-staff workers was one of active encouragement to remain at work until age 70 when, with the occasional exception of a highly skilled tradesman, all workers were retired, a small non-contributory pension being paid.

Small Foundry.-The small foundry was located one mile from the first foundry, the products and methods of manufacture being similar. Also long established, this foundry employed a total of 324 male non-staff weekly wage-earners of whom $68(21 \%)$ were aged 50 or over; 66 were interviewed, one man having left before his interview was due and one being absent through illness.

A small non-contributory pension was paid to retired workers but no age-limit was put on those who were fit and willing to do useful work.

The Coal-mine.-One of the largest in Scotland, it employed 1,450 men and had been in production for 30 years. By comparison with other pits, it had been little affected by economic vicissitudes and was reckoned to have a fairly stable labour force.

Three hundred and thirty-nine men (22\%) were listed as being aged 50 years or over and of these 200 were interviewed. Whereas in the foundries no serious obstacles were encountered in obtaining a $90 \%$ sample for interview, access to about one-third of the miners was either impossible or so difficult for occupational reasons, shift work, location of faces and headings, etc., that the attempt to obtain a truly representative sample had to be abandoned. 
Eventually a simple selection procedure was adopted. From a list of dates of birth, men aged 50 years and over were asked in sequence to come for interview; if available and willing (there were two refusals) they were seen. At least 43 men were not available through sickness absence and 12 had left to work elsewhere before their names were reached.

The colliery manager held the view that since no rigid age for retirement was laid down (the miners' pension scheme was not then in operation) older men should be encouraged to remain at work so long as they retained a useful capacity for work.

\section{Findings}

"Work Heaviness"-Using the opinions of workers, supervisors, and the investigator, each man's job at the time of interview was graded as heavy, medium, or light. The distinction between these categories is blurred and they can more correctly be regarded as three overlapping parts of a range. The inevitable error in so subjective a grouping was to some extent reduced by the small number of defined occupations within which variation could occur.

Table 3 shows the distribution of "workheaviness" in each of the three industrial units.

There is a fall from the 50 s through the 60 s to the 70s in the proportion of men on heavy work but only in the data from the coal-mine is the difference significant at the conventional level. It is, however, necessary to consider the absolute numbers from which these proportions are derived; between each decade of age there is a sharp drop in the numbers at work due to the combined effect, if the study were a "continuous" one, of death, illness, and retirement. (The assumption is made that losses due to men leaving to seek work elsewhere are balanced by gains from moves in the opposite direction.) If these factors or any one of them operated selectively on men in the heavy grade of work at a given age, then clearly the older "work heaviness" distribution would show a decline in the proportion of men on heavy work. Scrutiny of the absolute figures provides only one clue to the contrary, the increase from 15 men aged $50-59$ to 25 men aged $60-69$ in the light work column of the coal-mine data. This could only be due to a redistribution of "work heaviness" between these ages. Therefore an explanation of the findings in Table 3 requires analysis of the occupational histories for evidence of moves to less heavy work.

Moves to Less Heavy Work.-It was seldom difficult to reconcile admitted moves to less heavy work with the evidence from the work history but to be content with admitted changes only would have ignored many obvious discrepancies in the past work record. Such changes as enumerated in the subsequent tables include therefore both admitted and unadmitted moves to less heavy work.

Individuals were placed in one of two groups. Group I contains those men in whose history there was no detectable evidence of a move to lighter work. Group II contains those who had transferred to lighter work. One possible source of error must be mentioned; there seemed to be an accepted tradition that older men. should "ease up", this being expressed in such phrases as "I don't get the heaviest tasks now" and "I'm allowed to take my own time". While confirmation of this was sometimes obtained, such ill-defined changes were not classed as changes to lighter work.

TABLE 3

WORK DISTRIBUTION BY AGE GROUPS

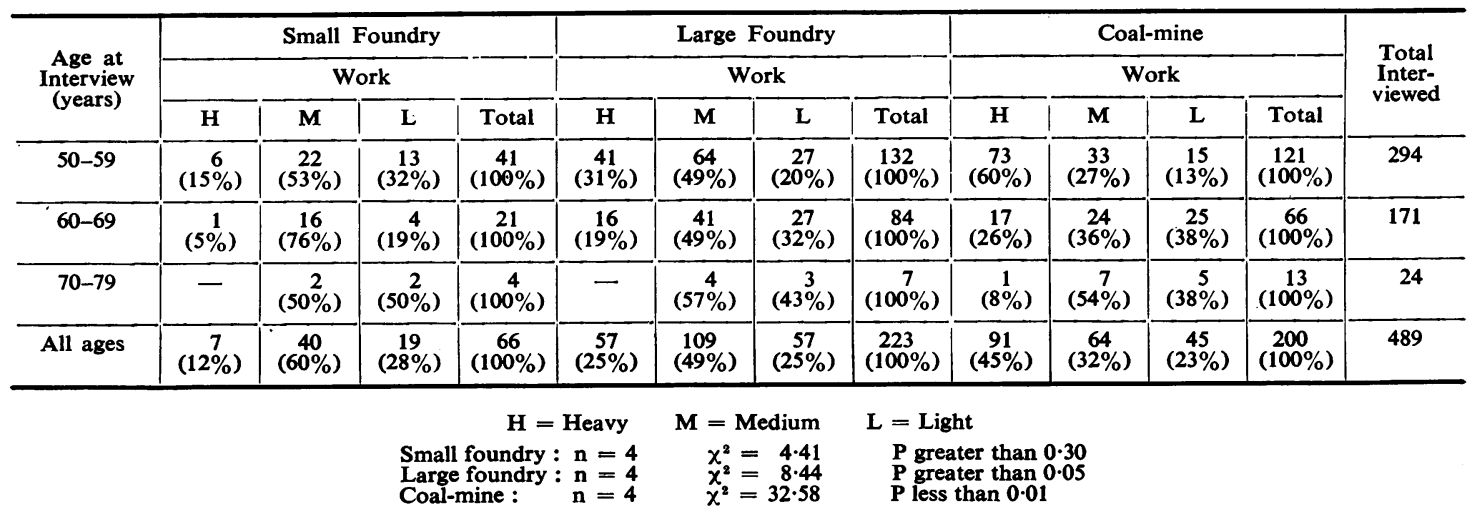


TABLE 4

INCIDENCE OF CHANGE TO LIGHTER WORK IN AGE-GROUPS

\begin{tabular}{|c|c|c|c|c|c|c|c|c|c|}
\hline \multirow{2}{*}{$\underset{\text { Interview }}{\text { Age at }}$} & \multicolumn{3}{|c|}{ Small Foundry } & \multicolumn{3}{|c|}{ Large Foundry } & \multicolumn{3}{|c|}{ Coal-mine } \\
\hline & Group I & Group II & Total & Group I & Group II & Total & Group I & Group II & Total \\
\hline $50-59$ & $\begin{array}{c}16 \\
(39 \%)\end{array}$ & $\begin{array}{c}25 \\
(61 \%)\end{array}$ & $\begin{array}{c}41 \\
(100 \%)\end{array}$ & $\begin{array}{c}68 \\
(52 \%)\end{array}$ & $\begin{array}{c}64 \\
(48 \%)\end{array}$ & $\begin{array}{c}132 \\
(100 \%)\end{array}$ & $\begin{array}{c}56 \\
(46 \%)\end{array}$ & $\begin{array}{c}65 \\
(54 \%)\end{array}$ & $\begin{array}{c}121 \\
(100 \%)\end{array}$ \\
\hline $60-69$ & $\begin{array}{c}8 \\
(38 \%)\end{array}$ & $\begin{array}{c}13 \\
(62 \%)\end{array}$ & $\begin{array}{c}21 \\
(100 \%)\end{array}$ & $\begin{array}{c}23 \\
(27 \%)\end{array}$ & $\begin{array}{c}61 \\
(73 \%)\end{array}$ & $\begin{array}{c}84 \\
(100 \%)\end{array}$ & $\begin{array}{c}13 \\
(20 \%)\end{array}$ & $\begin{array}{c}53 \\
(80 \%)\end{array}$ & $\begin{array}{c}66 \\
(100 \%)\end{array}$ \\
\hline $70-79$ & $(25 \%)$ & $(75 \%)$ & $\begin{array}{c}4 \\
(100 \%)\end{array}$ & $\left(43 \frac{3}{\%}\right)$ & $\begin{array}{c}4 \\
(57 \%\end{array}$ & $\left(\begin{array}{c}7 \\
(100 \%)\end{array}\right.$ & 一 & $\begin{array}{c}13 \\
(100 \%)\end{array}$ & $\begin{array}{c}13 \\
(100 \%)\end{array}$ \\
\hline Totals & $\begin{array}{c}25 \\
(38 \%)\end{array}$ & $\begin{array}{c}41 \\
(62 \%)\end{array}$ & $\begin{array}{c}66 \\
(100 \%)\end{array}$ & $\begin{array}{c}94 \\
(42 \%)\end{array}$ & $\begin{array}{l}129 \\
(58 \%)\end{array}$ & $\begin{array}{c}223 \\
(100 \%)\end{array}$ & $\begin{array}{c}69 \\
(34 \cdot 5 \%)\end{array}$ & $\begin{array}{c}131 \\
(65 \cdot 5 \%)\end{array}$ & $\begin{array}{c}200 \\
(100 \%)\end{array}$ \\
\hline
\end{tabular}

Group $I=$ no change. Group $I I=$ change.

$\begin{array}{lll}\text { Small foundry : } \mathrm{n}=2 & \chi^{2}=0.31 & \text { P greater than } 0.80 \\ \text { Large foundry }: \mathrm{n}=2 & \chi^{2}=12.26 & \text { P less than } 0.01\end{array}$

$\begin{array}{llll}\text { Large foundry : } & \mathrm{n}=2 \\ \text { Coal-mine : } & \mathrm{n}=2\end{array} \quad \begin{array}{ll}\chi^{2}=12.26 & \text { P less than } 0.01 \\ \chi^{2}=20.68 & \text { P less than } 0.01\end{array}$

Table 4 shows the distribution of the two groups.

No significance can be attached to the figures from the small foundry, but in the large foundry and the coal-mine there is a sharp increase from the $50 \mathrm{~s}$ to the $60 \mathrm{~s}$ in the proportion of men who had transferred to lighter work. In the coalmine data, the trend continues through to the 70s ; the change of trend in the 70s in the large foundry may be chance variation, but is more probably due to the "selection by skill" policy operated beyond the age of 70 in that firm.

One possible explanation of the difference in Table 4 between the 50 s and 60 s is that as a group the latter might in the past have been employed on heavier work than those 10 years younger, and could therefore be expected to show a higher rate of transfer at the same age. To assess this source of error in interpretation a comparison is made in Table 5 between the pre-transfer work of the two age-groups.

There are no significant differences between the two age-groups in respect of their "work heaviness" before transfer; the rise with age in the proportion of men in Group II (Table 4) must be otherwise explained.
The second possibility is that comparability between the age groups has been disturbed by the factors adduced above. In Table 4 from the 50s to the 60s (assuming that the observed differences would appear in a continuous study) the absolute numbers of men at work in the small foundry, large foundry, and coal-mine drop by 20,48 , and 55 respectively. If the cause of these differences, death, moribidity, unemployment (including retirement), were selectively influencing Group I men in the 50s, then without further transfer the observed variation in proportions could be accounted for.

Evidence will later be led to show that changes to lighter work were taking place at all ages, and therefore it can be concluded that the increase from the $50 \mathrm{~s}$ to the $60 \mathrm{~s}$ in the proportion of men who had changed to lighter work is the result of two events, losses from the labour force and transfers within the labour force.

Skill and Transfer to Lighter Work.-In view of the common belief that skilled older men encounter fewer problems than those less skilled, it seemed worthwhile to examine the relation between the level of industrial skill and the

TABLE 5

“ WORK HEAVINESS" OF GROUP II MEN BEFORE TRANSFERENCE TO LIGHTER WORK

\begin{tabular}{|c|c|c|c|c|c|c|c|c|c|}
\hline \multirow{3}{*}{$\begin{array}{l}\text { Age at } \\
\text { Interview }\end{array}$} & \multicolumn{9}{|c|}{ "Work Heaviness" before Transference to Lighter Work } \\
\hline & \multicolumn{3}{|c|}{ Small Foundry } & \multicolumn{3}{|c|}{ Large Foundry } & \multicolumn{3}{|c|}{ Coal-mine } \\
\hline & $\mathbf{H}$ & $\mathbf{M}$ & $\mathbf{L}$ & $\mathbf{H}$ & $\mathbf{M}$ & $\mathbf{L}$ & $\mathbf{H}$ & $\mathbf{M}$ & $\mathbf{L}$ \\
\hline $50-59$ & $\begin{array}{c}17 \\
(68 \%)\end{array}$ & $\begin{array}{c}8 \\
(32 \%)\end{array}$ & 一 & $\begin{array}{c}48 \\
(75 \%)\end{array}$ & $\begin{array}{c}16 \\
(25 \%)\end{array}$ & - & $\begin{array}{c}63 \\
(97 \%)\end{array}$ & $\left(\begin{array}{c}2 \\
3 \%\end{array}\right)$ & - \\
\hline \multirow[t]{2}{*}{$60-69$} & $\begin{array}{c}10 \\
(77 \%)\end{array}$ & $\left(23^{3} \%\right)$ & 一 & $\begin{array}{c}49 \\
(80 \%)\end{array}$ & $\begin{array}{c}12 \\
(20 \%)\end{array}$ & - & $\begin{array}{c}52 \\
(98 \%)\end{array}$ & $(2 \%)$ & - \\
\hline & \multicolumn{3}{|c|}{$\begin{array}{l}\text { S.E. of difference between } 68 \% \text { and } \\
77 \%=15.5 \%\end{array}$} & \multicolumn{3}{|c|}{$\begin{array}{l}\text { S.E. of difference between } 75 \% \text { and } \\
80 \%=7.4 \%\end{array}$} & \multicolumn{3}{|c|}{$\begin{array}{l}\text { S.E. of difference between } 97 \% \text { and } \\
98 \%=2.9 \%\end{array}$} \\
\hline
\end{tabular}


TABLE 6

SKILL DISTRIBUTION BY AGE OF MEN NOT TRANSFERRED TO LIGHTER WORK (GROUP I) IN FOUNDRIES ONLY

\begin{tabular}{c|c|c|c|c}
\hline $\begin{array}{c}\text { Age at } \\
\text { Interview }\end{array}$ & Skilled & Semiskilled & Unskilled & Totals \\
\hline $50-59$ & $\begin{array}{c}41 \\
(49 \%)\end{array}$ & $\begin{array}{c}25 \\
(30 \%)\end{array}$ & $\begin{array}{c}18 \\
(21 \%)\end{array}$ & $\begin{array}{c}84 \\
(100 \%)\end{array}$ \\
\hline $60-69$ & $\begin{array}{c}19 \\
(61 \%)\end{array}$ & $\begin{array}{c}7 \\
(23 \%)\end{array}$ & $\begin{array}{c}5 \\
(16 \%)\end{array}$ & $\begin{array}{c}31 \\
(100 \%)\end{array}$ \\
\hline $70-79$ & $\begin{array}{c}4 \\
(100 \%)\end{array}$ & - & - & $\begin{array}{c}4 \\
(100 \%)\end{array}$ \\
\hline Totals & $\begin{array}{c}64 \\
(54 \%)\end{array}$ & $\begin{array}{c}32 \\
(27 \%)\end{array}$ & $\begin{array}{c}23 \\
(19 \%)\end{array}$ & $\begin{array}{c}119 \\
(100 \%)\end{array}$ \\
\hline$\chi^{2}=4.98$ & & $n=4$ & p=greater than 0.20
\end{tabular}

incidence of change to lighter work. The coal miners proved extremely difficult to grade, there being no clear distinction between one level of skill and the next; they are therefore excluded from numerical consideration though, as will be discussed later, there was some evidence that the pattern of skill and age was similar to that shown below for the foundries. Grading of skill was based on length of training, recognition by trade unions, wage rates and "status". With the help of supervisors each man was placed in the appropriate group, and, since the range of jobs was very similar in the two foundries, the data from them have been combined in Tables 6 and 7 .

Chance fluctuation may be responsible for the observed differences with age in proportions (Table 6) but if the effect of age is real a twofold explanation is likely. The absolute numbers reveal that the losses between the $50 \mathrm{~s}$ and the

TABLE 7

DISTRIBUTION OF SKILL BEFORE AND AFTER CHANGE TO LIGHTER WORK BY AGE GROUPS (COMBINED DATA FROM FOUNDRIES)

\begin{tabular}{c|c|c|c|c|c|c|c|c}
\hline $\begin{array}{c}\text { Age at } \\
\text { Inter- } \\
\text { view }\end{array}$ & \multicolumn{3}{|c|}{$\begin{array}{c}\text { Group II before Transfer } \\
\text { to Lighter Work }\end{array}$} & \multicolumn{3}{|c}{$\begin{array}{c}\text { Group II after Transfer } \\
\text { to Lighter Work }\end{array}$} \\
\hline S & SS & US & Total & S & SS & US & Total \\
\hline $50-59$ & $\begin{array}{c}51 \\
(57 \%)\end{array}$ & $\begin{array}{c}23 \\
(25 \%)\end{array}$ & $\begin{array}{c}16 \\
(18 \%)\end{array}$ & $\begin{array}{c}90 \\
(100 \%\end{array}$ & $\begin{array}{c}25 \\
(28 \%)\end{array}$ & $\begin{array}{c}15 \\
(17 \%)\end{array}$ & $\begin{array}{c}50 \\
(55 \%)\end{array}$ & $\begin{array}{c}90 \\
(100 \%)\end{array}$ \\
\hline $60-69$ & $\begin{array}{c}40 \\
(55 \%)\end{array}$ & $\begin{array}{c}18 \\
(25 \%)\end{array}$ & $\begin{array}{c}15 \\
(20 \%)\end{array}$ & $\begin{array}{c}73 \\
(100 \%)\end{array}$ & $\begin{array}{c}15 \\
(20 \%)\end{array}$ & $\begin{array}{c}8 \\
(11 \%)\end{array}$ & $\begin{array}{c}50 \\
(69 \%)\end{array}$ & $\begin{array}{c}73 \\
(100 \%)\end{array}$ \\
\hline $70-79$ & $\begin{array}{c}5 \\
(71 \%)\end{array}$ & $\begin{array}{c}29 \%) \\
(29 \%)\end{array}$ & - & $\begin{array}{c}7 \\
(100 \%)\end{array}$ & $\begin{array}{c}1 \\
(14 \%)\end{array}$ & $\begin{array}{c}3 \\
(43 \%)\end{array}$ & $\begin{array}{c}3 \\
(43 \%)\end{array}$ & $\begin{array}{c}7 \\
(100 \%)\end{array}$ \\
\hline Totals & $\begin{array}{c}96 \\
(57 \%)\end{array}$ & $\begin{array}{c}43 \\
(25 \%)\end{array}$ & $\begin{array}{c}31 \\
(18 \%)\end{array}$ & $\begin{array}{c}170 \\
(100 \%)\end{array}$ & $\begin{array}{c}41 \\
(24 \%)\end{array}$ & $\begin{array}{c}26 \\
(15 \%)\end{array}$ & $\begin{array}{c}103 \\
(61 \%)\end{array}$ & $\begin{array}{c}170 \\
(100 \%)\end{array}$ \\
\hline
\end{tabular}

$\mathbf{S}=$ Skilled. $\quad \mathbf{S S}=$ Semiskilled. $\quad$ US $=$ Unskilled.

Age 50-59: standard error of difference between $57 \%$ and $28 \%$ $=9.9$.

Age 60-69 : standard error of difference between $55 \%$ and $20 \%$ $=10 \cdot 5$.

Age 70-79 : standard error of difference between $71 \%$ and $14 \%$ $=30 \cdot 2$.
60 s are relatively greater in the semi-skilled (18 out of 25$)$ and unskilled (13 out of 18) groups than in the skilled group (22 out of 41 ); these losses may have been either through transfer to Group II or through the several factors already referred to which operated to remove men from the labour force.

Inasmuch as the reduction from the 50 s to the $60 \mathrm{~s}$ is relatively lighter in the skilled group, the latter is more fortunate but consideration of the facts from Group II indicates that at least one important group of skilled men had encountered difficulties. Table 7 shows the skills distribution before and after transfer to lighter work.

In the age groups $50-59$ and $60-69$, the observed difference between the pre- and posttransference proportions of skilled men is three times the standard error. This significant difference permits the conclusion that a change to lighter work was frequently associated with a reduction in skill.

The reason for this strong correlation between moves to less heavy work and drop in skill is to be found in the nature of one of the main occupations in these foundries, ironmoulding. There were three fairly distinct grades of moulder ; all merited the title "skilled" in the sense that a full apprenticeship was required for entry but in the two higher grades the speed of work was lower, the accuracy demanded was higher, and timerates were paid. The majority of moulders were employed in the third grade where the tempo of work was rapid and piece-rates paid. Some exchange between grades took place, but men employed for many years in the lowest grade seldom attempted or were encouraged to attempt re-mastery of the higher skills; when a move to less heavy work was made, it was usually away from iron-moulding, a trend which largely accounts for the figures in Table 7.

Age at Transfer.-A few men - had obvious difficulty in remembering dates, and in such cases the most that could usually be achieved was to narrow the date down to a particular agedecade, if the change was early in working life or to a five-year period if it was more recent. It is very probable that some early job changes were forgotten, but that very few of these would rank as transfers to lighter work was suggested by the replies of a number of foremen and supervisors to questions on how often men in the 20s and 30 s sought less heavy work. At these ages such requests were rare, and, therefore, although 
the number of such recorded transfers in the early decades may be a slight under-estimate, this is not reckoned to be a serious source of error.

In presenting the findings account has been taken of the fact that the maximum age at change to lighter work was determined by the age at interview. Table 8 shows the crude relationship between the two ages.

There were five men in whose histories two separate permanent changes to lighter work were recorded; to avoid confusion only the earlier of each pair has been included. It is seen that in general, the older the men were at interview the later had they changed to lighter work. It is safe to assume that this relationship is partly the result of a process of selection; many of the men changing to lighter work in the 40s and 50s would be unfit or unwilling to continue at work, and their more able contemporaries who reached the 60 s before transferring to less heavy tasks would inevitably show a higher mean age at the time of their move, the 70 s repeating the pattern at a still higher average age.

To determine the true relation between age and transference to lighter work within the limits imposed by this selection effect, tables have been constructed to show, for each of the three industrial units, the rate of transfer at different ages. This rate was calculated by dividing the number of changes to lighter work by the total number at risk in each age period and then reducing the resulting figure to a rate per year. The number at risk during any given period comprised all those who had not previously changed to lighter work, and the tables therefore cover all men interviewed.
Tables A, B, and C, in the appendix, set out the results of this analysis.

In each age-group in each industrial grouping there is a distinct trend in the pattern of transfer to lighter work; the rate rises from a low level in the $20 \mathrm{~s}$ and $30 \mathrm{~s}$, becoming higher as the theoretical maximum age is approached. The curves are shown in Fig. 1 (overleaf).

The similarity between the curves suggests the operation of some common factor from about the age of 40 onwards, and it is now necessary to construct a hypothesis to explain these findings. We must consider the effect upon these curves which would result from the inclusion of two groups of men similar in age composition to those interviewed and formerly employed in the same industries but who had either retired, become unemployed, died, or were otherwise inaccessible at the time of study. It is again assumed that men going out to lighter work elsewhere were balanced by those coming in to lighter work.

The first of these two groups comprises men who had not changed to lighter work before giving up employment; including these men in the data would raise the number at risk (n) in each age period up to the time of their retirement (or unemployment) without affecting the number of changes, and thus the rate of change would at first be lowered but their retirement would reduce the number at risk thereby producing a sharp rise in the rate. The effect would be to steepen the curves shown in Fig. 1.

The second group to be considered consists of men who changed to lighter work and continued on it for a period and then retired. Their addition

TABLE 8

NUMBERS OF MEN CHANGING TO LIGHTER WORK AT EACH AGE BY AGE-GROUPS AT TIME OF INTERVIEW

\begin{tabular}{|c|c|c|c|c|c|c|c|c|c|c|c|c|c|c|c|c|c|c|c|}
\hline \multirow{3}{*}{$\begin{array}{c}\text { Age at } \\
\text { Transfer }\end{array}$} & \multicolumn{18}{|c|}{ Age at Interview } & \multirow{3}{*}{ Totals } \\
\hline & \multicolumn{3}{|c|}{$50-54$} & \multicolumn{3}{|c|}{$55-59$} & \multicolumn{3}{|c|}{$60-64$} & \multicolumn{3}{|c|}{$65-69$} & \multicolumn{3}{|c|}{$70-74$} & \multicolumn{3}{|c|}{$75-79$} & \\
\hline & $\overline{\mathrm{SF}}$ & $\overline{L F}$ & $\mathrm{CM}$ & SF & LF & $\mathrm{CM}$ & SF & LF & $\mathrm{CM}$ & SF & LF & $\mathrm{CM}$ & SF & LF & $\mathrm{CM}$ & SF & LF & $\overrightarrow{C M}$ & \\
\hline $20-29$ & - & 1 & - & 1 & 1 & - & - & 1 & 1 & - & - & - & - & - & - & - & - & - & 5 \\
\hline $30-39$ & - & 5 & 4 & - & 2 & - & $1-$ & 5 & - & 2 & 1 & - & - & - & - & - & 1 & - & 20 \\
\hline $40-49$ & 7 & 19 & 19 & 1 & 7 & 7 & 2 & 6 & 3 & - & 3 & 1 & - & - & 1 & - & - & - & 76 \\
\hline $50-54$ & 5 & 10 & 9 & 4 & 9 & 16 & - & 5 & 3 & 1 & 3 & 2 & 1 & - & 1 & - & - & - & 69 \\
\hline $55-59$ & - & 1 & - & 7 & 10 & 10 & 1 & 8 & 15 & 2 & 8 & 3 & - & 1 & 2 & - & 1 & 1 & 69 \\
\hline $60-64$ & - & - & - & - & - & - & 3 & 6 & 7 & 1 & 8 & 10 & 1 & 1 & 1 & - & - & - & 38 \\
\hline $65-69$ & - & - & - & - & $1-$ & - & $1-$ & - & - & 1 & 7 & 8 & - & - & 4 & - & - & - & 20 \\
\hline $70-74$ & - & - & - & - & - & - & - & - & - & - & - & - & 1 & - & 2 & - & $1-$ & 1 & 4 \\
\hline $75-79$ & - & - & - & - & $1-$ & - & - & - & - & - & - & - & - & $1-$ & - & - & - & - & - \\
\hline
\end{tabular}

SF $=$ Small Foundry.$\quad$ LF $=$ Large Foundry $. \quad \mathbf{C M}=$ Coal-mine 


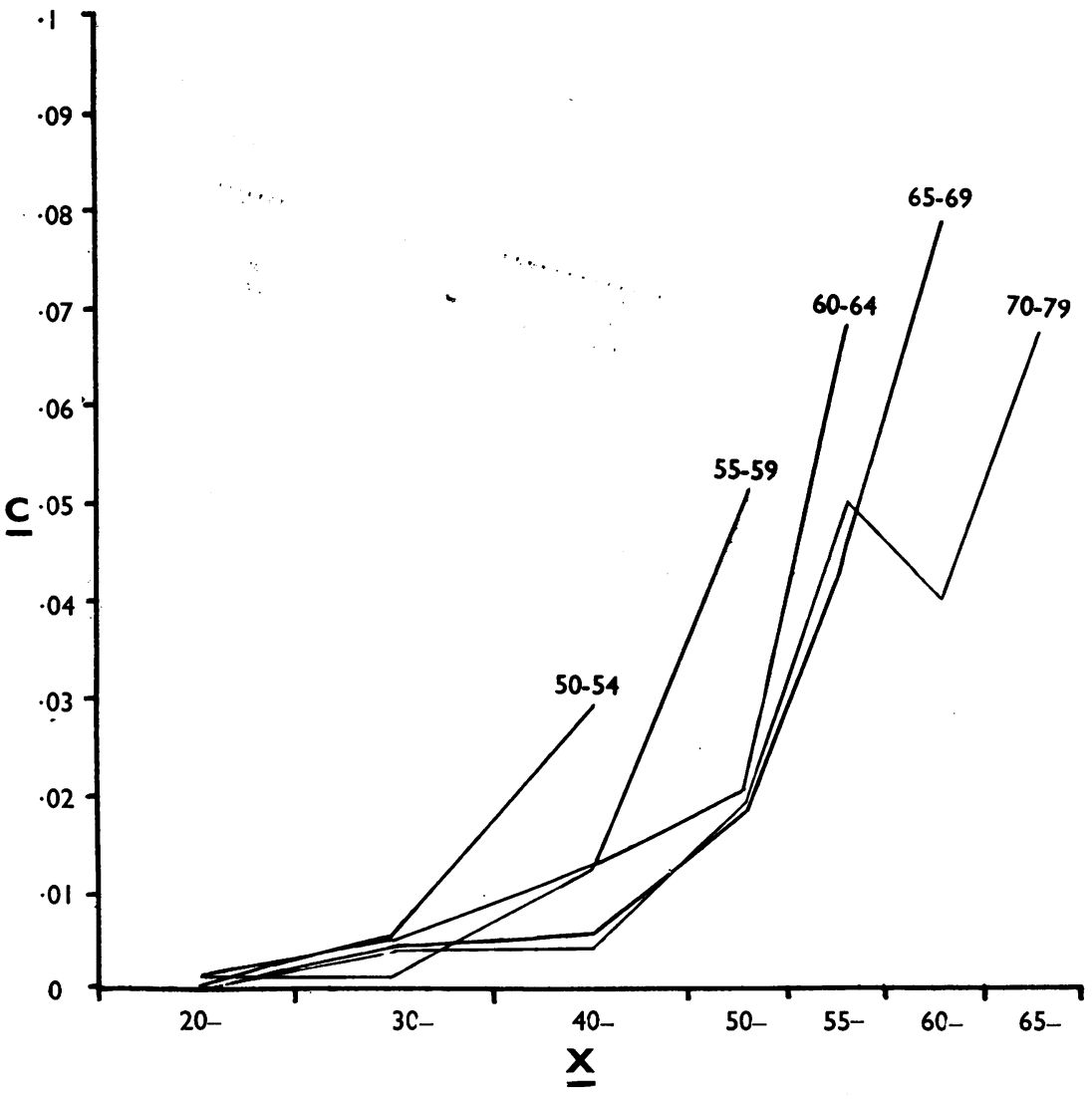

FiG. 1.-Graph of rates of transfer to lighter work by age-groups. $c=$ rate of transfer. $\quad x=$ age-periods at transfer.
The Role of Illness and Injury.-Sixty-two per cent. of the men who had moved to less heavy work declared that an illness or injury was responsible. The proportions in the three industrial groups are shown in Table 9.

Doctors are familiar with the tendency to implicate health when a change of work is sought; with this in mind every claim that a change to lighter work had been on health grounds was examined at interview and accepted only if either the medical diagnosis or an adequate description of the ailment was forthcoming.

The nature of the illness or injury varied from trivial to severe. There were cases in which the need for a change of work had been indisputable on grounds of major disability but an interesting and not uncommon type of history was that of a move off heavy work following a minor injury or illness from which recovery had been both rapid and complete. It seemed that many men carried on in heavy work under increasing strain until a " trigger-factor" such as illness or injury supervened and the decision to change to lighter work was made. Some of the histories strongly suggested that the influence of work-mates, family, or medical adviser was important in reaching that decision.

Other Factors.-At interview it was often clear that for reasons of prestige, men were anxious

TABLE 9

\begin{tabular}{c|c|c|c|c}
\hline Group & $\begin{array}{c}\text { Small } \\
\text { Foundry }\end{array}$ & $\begin{array}{c}\text { Large } \\
\text { Foundry }\end{array}$ & $\begin{array}{c}\text { Coal- } \\
\text { mine }\end{array}$ & Total \\
\hline $\begin{array}{c}\text { Proportion of moves } \\
\text { associated with } \\
\text { illness or injury }\end{array}$ & $\begin{array}{c}26 \\
\text { out of } \\
41 \\
(63 \%)\end{array}$ & $\begin{array}{c}73 \\
\text { out of } \\
129 \\
(57 \%)\end{array}$ & $\begin{array}{c}84 \\
\text { out of } \\
131 \\
(64 \%)\end{array}$ & $\begin{array}{c}183 \\
\text { out of } \\
301 \\
(62 \%)\end{array}$ \\
\hline
\end{tabular}
Standard error of $62 \%\left\{\begin{array}{l}\text { in samples of } 41=7 \cdot 8 \% \\ \text { in samples of } 129=4 \cdot 3 \% \\ \text { in samples of } 131=4 \cdot 2 \%\end{array}\right.$ Several factors, notably the role of illness and injury, must be considered. 
to justify their move from heavy work and were inclined to invoke rather specious factors. The use of such expressions as "strain", "my age", "shortness of breath", "fatigue", was common but one point clearly emerged, the actual move to less heavy work was often preceded by a period of weeks or months during which the individual became increasingly aware of the heaviness of his work. What finally decided the request for a lightening of effort was obscure but an occasional clue was obtained. The sudden death or illness of a fellow heavy worker was mentioned by seven men as having decided them to seek lighter work "before the same thing happens to me". Twentyfive miners stated that following the close-down of their former colliery they had not resumed heavy work. The falling vacant of a job where the duties were known to be light was given as the deciding factor by five men.

There appeared to be a similarity about the pattern of change whether this had followed illness or not ; a preliminary period of mounting awareness of the demands of heavy work, the actual move being determined by an event such as illness, injury, redundancy, or some external reminder of the supposed effects of age. The frequency with which "my age" was invoked to explain such a change in whole or in part was striking ; to many it was apparently an explanation which satisfied them and if this conventional belief is as strongly entrenched elsewhere as it was in these groups, it will be no easy. task to alter it.

Speed of Work.-All men, whether they had changed to lighter work or not, were invited to mention any features of their work which had caused difficulty as they grew older. The outstanding reply was about the effect of speed.

In the foundries two main groups of men, ironmoulders and stove-fitters, were paid by individual piece-rates. The moulders worked in pairs in order to assist each other with heavy lifts and as far as possible men of about the same age were selected as "neighbours". This arrangement worked well enough on the whole but of the 58 moulders who had changed to lighter work, five gave as their reason the strain of trying to keep up with the faster pace set by young " neighbours". But even when the moulders were evenly matched for speed, the rate of work necessary to maintain earnings was high, and since the work was strenuous at each phase of the cycle, ironmoulding was one of the heaviest jobs in the factory. The moulders were almost unanimous that with increasing age the continuity of piece-work imposed greater strain upon them and they had no hesitation in defining suitable work as that which allowed the moulder to regulate his own speed of work.

Seventeen stove-fitters who had moved off piecework were interviewed; though less strenuous than moulding the rate of work was also rapid. Some years previously the stove-fitters had worked in small groups, the piece-rate earnings being calculated on the group output. Four of the fitters interviewed had given up that system of piece-work, and it later transpired that these four had been moved at the request of the other and younger members of the group who complained that they were too old (all four were in the late 50s) to keep pace and were therefore hindering the earning capacity of the group.

From the interviews with miners the effect of speed was again evident. To reach the coalface or rock heading a walk of one mile from pit bottom was necessary (personal experience on some 20 occasions confirmed the strenuous nature of this task). The main cause of difficulty for the older men was not the distance so much as the pace at which it had to be covered if they were to keep up with the younger men in the group. "At my job I'm all right" was repeatedly heard at interview, and was confirmed by visits to the coalface where men in the late 50s who complained of marked shortness of breath on the hill up to the pit and on the way to the coalface could be seen stripping coal without visible distress. The reason appeared to be that at the coal seams rest pauses were largely under the individual's own control as they were on lone journeys to and from work.

Indeed the most important component of " light " or "lighter" work, as these terms were used by the men interviewed, was this opportunity to control the pace of work and the distribution of rest pauses. With the classification of "work heaviness" used in this study, it will be seen in Table 3 that relatively few men's jobs were classed as " light" yet the proportion of changes to lighter work was $50 \%$ or more; it is important to emphasize that men often moved to lighter work yet still remained in the moderate category or even (in a few cases) in the heavy category. Provided the effort was broken up by rest pauses, the intensity of effort seemed of secondary importance.

Age and Health.-It seemed worthwhile to attempt a crude division of the men interviewed into health categories, first to observe whether the distributions varied with age and secondly to see what kind of relation lay between health and work. 
TABLE 10

HEALTH CATEGORY BY AGE GROUPS BOTH
FOUNDRIES)

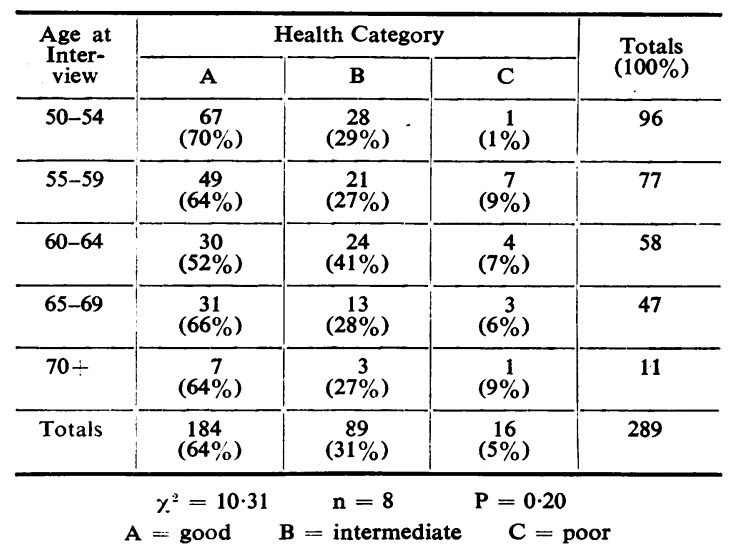

The assessments used were based on the account of past and present health, supplemented where possible by personal observation during interview. From the tabulated replies men were assigned to one of three categories :

Category A: Good Health.-Criteria were no past illness or injury affecting present health; unqualified statement that present health satisfactory; not receiving medical attention; no symptoms or disabilities.

Category C : Poor Health.-Criteria were history of past illness or injury affecting present health ; present health stated to be other than good; recent medical attention; presence of substantial disability restricting capacity for effort.

Category $B$ : Intermediate.-Criteria were general health good; presence of local disability. (The

TABLE 11

HEALTH CATEGORY BY AGE GROUPS IN THE COAL-MINE

\begin{tabular}{|c|c|c|c|c|}
\hline \multirow{2}{*}{$\begin{array}{l}\text { Age at } \\
\text { Inter- } \\
\text { view }\end{array}$} & \multicolumn{3}{|c|}{ Health Category } & \multirow{2}{*}{$\begin{array}{c}\text { Totals } \\
(100 \%)\end{array}$} \\
\hline & $\mathbf{A}$ & B & C & \\
\hline $50-54$ & $\begin{array}{c}49 \\
(74 \%)\end{array}$ & $\begin{array}{c}14 \\
(22 \%)\end{array}$ & $\begin{array}{c}3 \\
(4 \%)\end{array}$ & 66 \\
\hline $55-59$ & $\begin{array}{c}31 \\
(56 \%)\end{array}$ & $\begin{array}{c}22 \\
(40 \%)\end{array}$ & $\begin{array}{c}2 \\
(4 \%)\end{array}$ & 55 \\
\hline $60-64$ & $\begin{array}{c}17 \\
(44 \%)\end{array}$ & $\begin{array}{c}20 \\
(51 \%)\end{array}$ & $\begin{array}{c}2 \\
(5 \%)\end{array}$ & 39 \\
\hline $65-69$ & $\begin{array}{c}17 \\
(63 \%)\end{array}$ & $\begin{array}{c}10 \\
(37 \%)\end{array}$ & - & 27 \\
\hline $70+$ & $\begin{array}{c}13 \\
(100 \%)\end{array}$ & - & - & 13 \\
\hline Totals & $\begin{array}{c}127 \\
(63 \cdot 5 \%)\end{array}$ & $\begin{array}{c}66 \\
(33 \%)\end{array}$ & $\begin{array}{c}7 \\
(3.5 \%)\end{array}$ & 200 \\
\hline
\end{tabular}

presence of a minor temporary ailment such as a cold was ignored.)

The majority of assessments were easily categorized; with those who lay near the borderline between categories some difficulty was inevitable, but from the outset it was recognized that consistent assignment was of the utmost importance if even broad conclusions were to be drawn. No conscious consideration of the work being done was taken into account and allowance for age was left to the individual. The assessments were checked on three occasions at intervals of several months and it was found on each recheck that $94 \%$ were consistent.

Tables 10 and 11 show the distributions by age.

The association between age and health is stronger in the coal miners than in the foundry workers, but there is a distinct similarity between the distributions of men in Category $A$ in the two tables. The proportion of men in good health declines to the early 60 s and thereafter rises in the 65-69 age group, the upward trend continuing in the coal miners over age 70 . It is likely that the change of direction around age 65 is due to some of the less fit men having retired on reaching national pension age, leaving their contemporaries in good health to continue at work. Some support for this view was obtained at interview, a number of men in Categories $\mathbf{B}$ and $\mathrm{C}$ intimating their intention to keep at work if possible until age 65 when pensions would begin.

Age, Health, and Work.-The last association to be examined is that between the state of health and the heaviness of work. In Tables 12 and 13 are set out the comparisons by age between the work distributions within each health category.

The smaller proportion of men on heavy work in Categories $\mathbf{B}$ and $\mathbf{C}$ is expected in view of their disability. The finding of note is that among the men in good health there is a steady decline with age in the proportion on heavy work though in the foundry data this could easily be due to chance. It is of course wrong to equate Category A with fitness for heavy work, but it does appear that the decline with age in the proportion of men on heavy work cannot be attributed to state of health as such unless the proportional distributions have been upset by losses between one age-group and the next, and of this, there is in this study, no actual measure.

\section{Discussion}

Reference has been made to the methodological difficulties which confined this study to older people at work. The resulting restriction on interpretation of the data has been discussed 
TABLE 12

HEALTH CATEGORY AND “WORK HEAVINESS" IN THE TWO FOUNDRIES

\begin{tabular}{|c|c|c|c|c|c|c|c|c|c|}
\hline \multirow{2}{*}{$\begin{array}{c}\text { Age } \\
\text { Group }\end{array}$} & \multicolumn{3}{|c|}{ Category A } & \multicolumn{3}{|c|}{ Category B } & \multicolumn{3}{|c|}{ Category $\mathrm{C}$} \\
\hline & $\mathbf{H}$ & $\mathbf{M}$ & $\mathbf{L}$ & $\mathbf{H}$ & $\mathbf{M}$ & $\mathbf{L}$ & $\mathbf{H}$ & $\mathbf{M}$ & $\mathbf{L}$ \\
\hline $50-59$ & $\begin{array}{c}43 \\
(37 \%)\end{array}$ & $\begin{array}{c}58 \\
(50 \%)\end{array}$ & $\begin{array}{c}15 \\
(13 \%)\end{array}$ & $\begin{array}{c}4 \\
(8 \%)\end{array}$ & $\begin{array}{c}22 \\
(45 \%)\end{array}$ & $\begin{array}{c}23 \\
(47 \%)\end{array}$ & - & 6 & 2 \\
\hline $60-69$ & $\begin{array}{c}13 \\
(21 \%)\end{array}$ & $\begin{array}{c}35 \\
(57 \%)\end{array}$ & $\begin{array}{c}13 \\
(21 \%)\end{array}$ & $\begin{array}{c}3 \\
(8 \%)\end{array}$ & $\begin{array}{c}20 \\
(54 \%)\end{array}$ & $\begin{array}{c}14 \\
(38 \%)\end{array}$ & 1 & 2 & 4 \\
\hline $70+$ & - & $\begin{array}{c}6 \\
(86 \%) \\
\end{array}$ & $(14 \%)$ & - & - & $\begin{array}{c}3 \\
(100 \%)\end{array}$ & - & 一 & 1 \\
\hline \multirow[t]{2}{*}{ Total } & $\begin{array}{c}56 \\
(30 \%)\end{array}$ & $\begin{array}{c}99 \\
(54 \%)\end{array}$ & $\begin{array}{c}29 \\
(16 \%)\end{array}$ & $\begin{array}{c}7 \\
(8 \%)\end{array}$ & $\begin{array}{c}42 \\
(47 \%)\end{array}$ & $\begin{array}{c}40 \\
(45 \%)\end{array}$ & $\begin{array}{c}1 \\
(6 \%)\end{array}$ & $\begin{array}{c}8 \\
\left(50^{\circ} / 0\right.\end{array}$ & $\left.\begin{array}{c}7 \\
\left(44^{\circ}, 0\right.\end{array}\right)$ \\
\hline & \multicolumn{3}{|c|}{$\begin{aligned} x^{2} & =7.86 \\
\mathbf{n} & =4 \\
\mathbf{p} & =0.10\end{aligned}$} & & & & & & \\
\hline
\end{tabular}

$\mathrm{H}=$ heavy work. $\mathbf{M}=$ medium work. $\mathbf{L}=$ light work.

TABLE 13

HEALTH CATEGORY AND “WORK HEAVINESS" IN THE COAL-MINE

\begin{tabular}{|c|c|c|c|c|c|c|c|c|c|}
\hline \multirow{2}{*}{$\begin{array}{l}\text { Age } \\
\text { Group }\end{array}$} & \multicolumn{3}{|c|}{ Category A } & \multicolumn{3}{|c|}{ Category B } & \multicolumn{3}{|c|}{ Category C } \\
\hline & $\mathbf{H}$ & $\mathbf{M}$ & $\mathbf{L}$ & $\mathbf{H}$ & $\mathbf{M}$ & L & $\mathbf{H}$ & $\mathbf{M}$ & $\mathbf{L}$ \\
\hline $50-59$ & $\begin{array}{c}56 \\
(70 \%) \\
\end{array}$ & $\begin{array}{c}17 \\
(21 \%)\end{array}$ & $\begin{array}{c}7 \\
(9 \%)\end{array}$ & $\begin{array}{c}15 \\
(42 \%)\end{array}$ & $\begin{array}{c}14 \\
(39 \%)\end{array}$ & $\begin{array}{c}7 \\
(19 \%)\end{array}$ & 2 & 2 & 1 \\
\hline $60-69$ & $\begin{array}{c}15 \\
(44 \%)\end{array}$ & $\left(\begin{array}{c}11 \\
(32 \%)\end{array}\right.$ & $\begin{array}{c}8 \\
(24 \%)\end{array}$ & $\begin{array}{c}3 \\
(10 \%)\end{array}$ & $\begin{array}{c}13 \\
(43 \%)\end{array}$ & $\begin{array}{c}14 \\
(47 \%)\end{array}$ & - & - & 2 \\
\hline $70+$ & $(15 \%)$ & $\begin{array}{c}7 \\
(54 \%) \\
\end{array}$ & $\begin{array}{c}4 \\
(31 \%\end{array}$ & - & - & - & - & - & - \\
\hline \multirow[t]{2}{*}{ Total } & $\begin{array}{c}73 \\
(57 \%)\end{array}$ & $\begin{array}{c}35 \\
(28 \%)\end{array}$ & $\begin{array}{c}19 \\
(15 \%)\end{array}$ & $\begin{array}{c}18 \\
(27 \%)\end{array}$ & $\begin{array}{c}27 \\
(41 \%)\end{array}$ & $\begin{array}{c}21 \\
(32 \%)\end{array}$ & $(29 \%)$ & $(29 \%)$ & $\begin{array}{c}3 \\
\left(42^{\circ} \%\right.\end{array}$ \\
\hline & \multicolumn{3}{|c|}{$\begin{aligned} \chi^{2} & =17.85 \\
n & =4 \\
P & =0.01\end{aligned}$} & & & & & & \\
\hline
\end{tabular}

$\mathbf{H}=$ heavy work. $\mathbf{M}=$ medium work. $\mathbf{L}=$ light work.

in the appropriate places, but it must be stressed that without similar investigation of the same age groups in the unemployed and retired sections of the population who had worked in these industrial units, the picture is inevitably incomplete. Mindful of this limitation, answers to the four questions posed will be attempted. (1) Are older men doing less heavy work than their younger colleagues? There seems no doubt that, as between the $50 \mathrm{~s}, 60 \mathrm{~s}$, and $70 \mathrm{~s}$, the answer is that as a group they are, in the foundries and coal-mine visited. To some extent this finding is dependent upon the opportunity for transfer to less heavy work which was probably greater than the nature of the work might suggest ; thus the proportion of this particular colliery labour force aged 65 years and over was $4.1 \%$ compared with a figure of $3.3 \%$ for the whole mining population in that same year. During the investigation ample evidence was obtained of the enlightened and energetic managerial policy for the retention in useful work of older men.
(2) At what ages do men move to less heavy work? An attempt has been made to give some precision to the general impressions on this question ; if the assumptions about those who retire are correct then the data show clearly that the incidence of change to lighter work is negligible in the $20 \mathrm{~s}$ and $30 \mathrm{~s}$, begins to rise in the $40 \mathrm{~s}$, and thereafter rises steeply.

Reference has already been made to the sharp increase between the age groups 41-50 and 51-55 years in the upward trend of national unemployment (Table 1) and to the finding of Thomas and Osborne that the overall average age at retirement from full-time work was 62 years. There is some similarity between these trends and the way in which age at change to lighter work behaved in this study, and it is therefore tempting to regard retirement from full-time work, unemployment at later ages, and change to lighter work as being in part due to the same set of changes with age. In one sense (though not strictly that used in this paper) 
both retirement and unemployment are work "modifications" and it may be that the premature occurrence of these events is in many cases because a suitable change, i.e., less heavy work, is simply not available. Statements made by several men in both foundries and coal-mine left no doubt that a number of men would have been forced into retirement or unemployment if lighter work had not been provided.

It is most important to realize that the problems connected with the employment of older men frequently arise some years earlier than 65 years. Unfortunately there are no statistical data to show the relative roles of heavy and light work in this respect but it is probable that the age of retirement is earlier, other factors being equal, in the heaviest jobs than in work as a whole.

(3) With what factors are these moves associated ? Though illness, injury or disability resulting therefrom was stated to be the "cause" of nearly twothirds of the moves to less heavy work, scrutiny of the recorded ailment and duration of absence, together with the frequent admission that strain had preceded the actual change to lighter work, left very little doubt that illness or injury often acted as a " trigger factor".

From the histories of those with good insight it appeared that the decision to seek less heavy work was often the result of some external suggestion by workmates, members of the family, or a doctor, acting on a mind made more receptive by an absence, even a short one, from work. It is common experience that during absence from work the subjective capacity for physical effort declines and has to be restored by a graduated return to work, but the nature of the objective psychological and physiological changes is obscure.

In his Linacre lecture on old age Rolleston (1922) observed that after an illness "old age often comes on apace". Is it possible that there are detectable changes in fitness and skill during and following absence from work through illness and injury even when clinical recovery is complete? Further speculation on the exact role of these events is useless but this would seem to be an important field for study.

Of the factors responsible even less is known. Reference has been made to the similarity between changes to lighter work preceded by ill health and some of those where no such history was obtained. The period of strain or increasing awareness of the demands of heavy work again emerged as the predisposing cause, the actual change appearing to follow some chance-determined event. The remaining men were convinced either that they had not moved to less heavy work at all-which was perhaps wishful thinking-or that such a move was the right thing to do in the 50s or 60s.

It cannot be too strongly stressed that conventional beliefs about age and work exerted a powerful influence in the groups interviewed. One of the most formidable tasks in the campaign to retain older workers in heavy industry will be to reduce the wastage of skill and of efficiency which results from this emotional rather than rational attitude to heavy work. There is certainly one direction in which much could be achieved - the alteration of paymentby-results to suit the older worker.

Increasing mechanization with its attendant acceleration of production speeds is extending the range of jobs to which piece-rates, output bonus schemes, and other incentives can be applied. These devices assume that high speeds of work are possible, an assumption known to be less and less correct as age increases. That time-rates are preferable to older men even when they imply a substantial drop in wages was the opinion of many of the men interviewed. Discussions with the foundry and mine managements revealed the manifold difficulties to be overcome if older men are to continue at their skilled tasks and at the same time be allowed some reduction of effort. But it would surely be more efficient and economical to keep skills in action at a lower level of output than to allow the present drift toward less skilled work to continue.

During the investigation two interesting examples of the efficient use of older skilled men were noted. In the coal-mine a few of the older strippers were transferred to a training coalface where the assistance of the young trainees reduced the effort and where the journey to and from the pit bottom was rather less hurried. In the large foundry several of the older men had been transferred to a new mechanized plant where, although the pace of work was strenuous and only younger men were recruited, their skilled knowledge enabled them to supervise without actually expending much effort. These illustrations serve to introduce an important principle for older men on heavy work : modify the effort but preserve the skill.

(4) Crude as the assessments were, the findings suggest that with a sound placement policy heavy industry can employ a considerable proportion of unfit men. One third of the whole group had some degree of disability and at least $5 \%$ were severely restricted in the work they could do.

It is, however, not easy to resettle older men in a coal-mine where the number of jobs requiring little effort is small. In the group interviewed eight men had certified pneumoconiosis but at least twice that 
number were probable sufferers and the combination of dyspnoea due to ageing and to disease placed severe restrictions upon them. Yet, as has been pointed out, this colliery had a higher proportion of men over 65 in employment than the national average.

Some evidence was tabulated to suggest that retirements at age 65 were relatively commoner among the less fit men. Owing to the inaccessibility of those who had already retired it was unfortunately impossible to determine whether they had done so on health grounds, because suitable work was not available, or because they had no inclination to continue in employment beyond pensionable age. It was noticeable that the men still at work over 65 years of age had a " why should I retire " attitude to work. These points focus attention on the difficulties imposed by the fact that older people at work are highly selected.

\section{Conclusion}

Finally it is appropriate to reconsider the introductory recommendations on work which is suitable for older men. From the research on skill and fitness therein reviewed, it was shown that work which required a high speed of performance and a high expenditure of energy is in general unsuitable for the majority of older people. It might therefore be expected that when these conditions are combined older people would tend to move off such work.

In both foundries and coal-mine many older men were consciously aware of the strain imposed upon them by heavy work, and it appeared that their notion of heaviness comprised in varying degree the conditions mentioned above. Change to lighter work may therefore represent a process of adjustment to psycho-physiological strains, and if that suggestion is correct the main problem becomes one of how to permit that adjustment without sacrificing the productive skills involved, or, in other words, of " refining" the kind of change to lighter work described in this paper.

By way of peroration the words of Sir Frederic Bartlett (1951b)-than whom none is better qualified to speak-are fitting :

" But it can be regarded as certain that, given adequate medical care and a proper regard for the conditions of training and work which are appropriate for the particular age-ranges concerned, the great bulk of the members of any modern community ought to be able, over the whole of a full life-span, to continue to contribute to the productive skills which are essential in such a community, and to do so without undue fatigue or strain but to their own happiness and satisfaction."

\section{Summary}

The core of the problem of age and work is how to retain older workers in industry. An important part of the solution is the definition of suitable work for those in the upper age ranges in terms of skill, fitness, and motivation; some of the changes with age in these qualities are reviewed.

From the industrial standpoint the problem varies in nature. The scanty evidence on the relation between age and heavy work is discussed, and a study is reported in which 489 men age 50 years and over were interviewed in two foundries and a coalmine.

Within the limits imposed by the fact that older people at work are highly selected, it is shown that the proportion of men on heavy work declined from the 50s onwards, and with this move off heavy work there was frequently a reduction in skill. The incidence of changes to less heavy work appeared to be low in the 20s and 30s, began to rise in the 40s, and thereafter sharply increased. The effect of selection upon this trend is discussed.

Illness or injury, both trivial and otherwise, was associated with two-thirds of the changes to lighter work. The suggestion is advanced that these and other events acted as " trigger factors", the decision to change often being preceded by a period of increasing strain.

The role played by speed of work in determining decisions to change to lighter work is discussed; the need is stressed for some reduction in work tempo as age increases and the view expressed that such reduction should not be at the expense of skill.

Some evidence is put forward that less fit men try to continue at work until age 65 , their retirement having a selective effect upon the health distribution of those who carry on beyond that age. It is shown that even those in good health are to be found on less heavy work as age increases.

The problem of the relation of age and work appears some years earlier than pensionable age. The similarity between the trends with age in unemployment, retirement, and changes to lighter work is discussed.

To the National Coal Board (Scottish Division), the foundry managements, and the various trade unions I express grateful thanks for generous facilities and cordial cooperation. I am indebted to many colleagues but most of all to Mr. Alan T. Welford, M.A., Director of the Nuffield Unit for Research into Ageing at Cambridge, for his constant encouragement and wise counsel. Lastly, but very sincerely I thank the $\mathbf{4 8 9}$ men for this insight into their problem of age and work.

The statistical calculations were kindly checked for me by the staff of the Department of Statistics, University of Aberdeen. 
Table 1 is reproduced by kind permission of the Director of Statistics, Ministry of Labour. Table 2 is Crown Copyright and is reproduced with the consent of the Controller of H.M. Stationery Office.

\section{REFERENCES}

Bartlett, F. (1951a). British Journal of Industrial Medicine, 8, 209. - (1951b). Introduction to Skill and Age, ed. Welford, A. T. London.

Belbin, R. M., and Sewell, A. M. N. (1950). Personal communication. Cathcart, E. P., Hughes, D. E. R., and Chalmers, J. G. (1935). Rep. industr. Hlth Res. Board, Lond. No. 71

Crowden, G. P. (1928). Rep. industr. Fatig. Res. Board, Lond., No. 50 Cullumbine, H., Bibile, S. W., Wikramanayake, T. W., and Watson R. S. (1950). J. appl. Physiol., 2, 488.

Fleming, C. (1952). Report on Age Analysis of Iron and Steel Industry. Unpublished.

Hugh-Jones, P.( 1952). Brit. med. J., 1, 65.
Industrial Welfare Society (1950). The Employment of Elderly Workers: Report of a Survey on the Practice and Experience of 400 Member Firms.

Ministry of Labour Gazette (1951), 59, 226.

Pemberton, J., and Smith, J. C. (1949). Brit. med. J., 2, 306.

Richardson, I. M. (1953). In the press.

Robinson, S. (1938). Arbeitsphysiologie, 10, 251.

Rolleston, H. (1922). Some Medical Aspects of Old Age. (Linacre Lecture.) London.

Royal Commission on Population (1949). Report. Cmd. 7695,

Sheldon, J. H. (1948). The Social Medicine of Old Age : Report of an Inquiry in Wolverhampton. Oxford University Press, London. Shock, N. W. (1947). J. Geront., 2, 93.

Shock, N. W. (1947). J. Geront., 2, 93.

Thomas, G., and Osborne, B. (1950). Older People and Their Employment. Social Survey Rep. No. 150. Central Office of Information, London.

Welford, A. T. (1950). The 19th Century and After, 148, 98.

(1951). Skill and Age. Oxford University Press, London

\section{A P P E N D I X}

TABLE A

RATES OF CHANGE TO LIGHTER WORK OF 50-54 and 55-59 AGE GROUPS

\begin{tabular}{|c|c|c|c|c|c|c|c|c|c|c|c|c|c|c|c|c|}
\hline \multirow{2}{*}{$\begin{array}{l}\text { Age } \\
\text { Period } \\
\quad x\end{array}$} & \multicolumn{4}{|c|}{ Small Foundry } & \multicolumn{4}{|c|}{ Large Foundry } & \multicolumn{4}{|c|}{ Coal-mine } & \multicolumn{4}{|c|}{ Total } \\
\hline & $\mathbf{n}$ & $\mathbf{m}$ & $\mathbf{r}$ & c & $\mathbf{n}$ & $\mathrm{m}$ & $\mathbf{r}$ & c & $\mathbf{n}$ & $\mathrm{m}$ & $\mathbf{r}$ & c & $\mathbf{n}$ & m & $\mathbf{r}$ & c \\
\hline $\begin{array}{c}\text { Men aged } 50 \\
20-29 \\
30-39 \\
40-49\end{array}$ & $\begin{array}{l}\text { yea } \\
22 \\
22 \\
22\end{array}$ & $\frac{-}{7}$ & $\overline{\overline{0}} \overline{318}$ & $\frac{\bar{Z}}{0.0318}$ & $\begin{array}{l}74 \\
73 \\
68\end{array}$ & $\begin{array}{r}1 \\
5 \\
19\end{array}$ & $\begin{array}{l}0.013 \\
0.068 \\
0.279\end{array}$ & $\begin{array}{l}0.0013 \\
0.0068 \\
0.0279\end{array}$ & $\begin{array}{l}66 \\
66 \\
62\end{array}$ & $\begin{array}{r}-4 \\
19\end{array}$ & $\begin{array}{l}0 . \overline{06} \\
0.306\end{array}$ & $\begin{array}{l}0 . \overline{006} \\
0.0306\end{array}$ & $\begin{array}{l}162 \\
161 \\
152\end{array}$ & $\begin{array}{r}1 \\
9 \\
45\end{array}$ & $\begin{array}{l}0.006 \\
0.055 \\
0.296\end{array}$ & $\begin{array}{l}0.0006 \\
0.0055 \\
0.0296\end{array}$ \\
\hline $\begin{array}{c}\text { Men aged } 55 \\
20-29 \\
30-39 \\
40-49 \\
50-54\end{array}$ & $\begin{array}{l}\text { yea } \\
19 \\
18 \\
18 \\
17\end{array}$ & $\frac{1}{1}$ & $\begin{array}{l}0.052 \\
\overline{0.055} \\
0.235\end{array}$ & $\begin{array}{l}0.0052 \\
0 . \overline{0055} \\
0.047\end{array}$ & $\begin{array}{l}58 \\
57 \\
55 \\
48\end{array}$ & $\begin{array}{l}1 \\
2 \\
7 \\
9\end{array}$ & $\begin{array}{l}0.017 \\
0.035 \\
0.127 \\
0.187\end{array}$ & $\begin{array}{l}0.0017 \\
0.0035 \\
0.0127 \\
0.0374\end{array}$ & $\begin{array}{l}55 \\
55 \\
55 \\
48\end{array}$ & $\begin{array}{r}- \\
7 \\
16\end{array}$ & $\begin{array}{l}\bar{Z} \\
\overline{0.127} \\
0.333\end{array}$ & $\begin{array}{c}-\overline{-} \\
0.0127 \\
0.0666\end{array}$ & $\begin{array}{l}132 \\
130 \\
128 \\
113\end{array}$ & $\begin{array}{r}2 \\
2 \\
15 \\
29\end{array}$ & $\begin{array}{l}0.015 \\
0.015 \\
0.117 \\
0.256\end{array}$ & $\begin{array}{l}0.0015 \\
0.0015 \\
0.0117 \\
0.0512\end{array}$ \\
\hline
\end{tabular}

$\mathrm{n}=$ number of men entering each age period of $\mathrm{x}$ years with no history of modification.

$\mathrm{m}=$ number of men modifying in each age period $\mathrm{x}$ ( $\mathrm{x}$ has only

$\mathbf{r}=$ crude modification rate $=\frac{m}{n}$

$m=$ number of men modifyin
two values $=5$ and 10 years).

$c=$ modification rate per year for each period $=\frac{r}{x}$

TABLE B

RATES OF CHANGE TO LIGHTER WORK OF 60-64 AND 65-69 AGE-GROUPS

\begin{tabular}{|c|c|c|c|c|c|c|c|c|c|c|c|c|c|c|c|c|}
\hline \multirow{2}{*}{$\underset{x}{\text { Period }}$} & \multicolumn{4}{|c|}{ Small Foundry } & \multicolumn{4}{|c|}{ Large Foundry } & \multicolumn{4}{|c|}{ Coal-mine } & \multicolumn{4}{|c|}{ Total } \\
\hline & $\mathbf{n}$ & $\mathrm{m}$ & $\mathbf{r}$ & c & $\mathbf{n}$ & $\mathrm{m}$ & $\mathbf{r}$ & c & $\mathbf{n}$ & m & $\mathbf{r}$ & c & $\mathbf{n}$ & m & $\mathbf{r}$ & c \\
\hline $\begin{array}{c}\text { Men aged } 60 \\
20-29 \\
30-39 \\
40-49 \\
50-54 \\
55-59\end{array}$ & $\begin{array}{r}y e a \\
10 \\
10 \\
10 \\
8 \\
8\end{array}$ & $\frac{\overline{2}}{\frac{2}{1}}$ & $\frac{\overline{\bar{T}}}{0 \cdot \overline{2}}$ & $\frac{\overline{-}}{0 . \overline{02}}$ & $\begin{array}{l}48 \\
47 \\
42 \\
36 \\
31\end{array}$ & $\begin{array}{l}1 \\
5 \\
6 \\
5 \\
8\end{array}$ & $\begin{array}{l}0 \cdot 02 \\
0 \cdot 106 \\
0 \cdot 142 \\
0 \cdot 138 \\
0 \cdot 258\end{array}$ & $\begin{array}{l}0.002 \\
0.0106 \\
0.0142 \\
0.0276 \\
0.0516\end{array}$ & $\begin{array}{l}39 \\
38 \\
38 \\
35 \\
32\end{array}$ & $\begin{array}{r}1 \\
3 \\
3 \\
15\end{array}$ & $\begin{array}{l}0.025 \\
0.078 \\
0.085 \\
0.468\end{array}$ & $\begin{array}{l}0.0025 \\
0.0078 \\
0.017 \\
0.0936\end{array}$ & $\begin{array}{l}97 \\
95 \\
90 \\
79 \\
71\end{array}$ & $\begin{array}{r}2 \\
5 \\
11 \\
8 \\
24\end{array}$ & $\begin{array}{l}0.02 \\
0.052 \\
0 \cdot 122 \\
0 \cdot 101 \\
0.338\end{array}$ & $\begin{array}{l}0.002 \\
0.0052 \\
0.0122 \\
0.0202 \\
0.0676\end{array}$ \\
\hline $\begin{array}{c}\text { Men aged } 6 \\
20-29 \\
30-39 \\
40-49 \\
50-54 \\
55-59 \\
60-64\end{array}$ & $\begin{array}{l}\text { yea } \\
11 \\
11 \\
9 \\
9 \\
8 \\
6\end{array}$ & $\begin{array}{c}\overrightarrow{2} \\
1 \\
2 \\
1\end{array}$ & $\begin{array}{l}\overline{0.181} \\
\overline{1} \\
0 \cdot 111 \\
0 \cdot 25 \\
0 \cdot 166\end{array}$ & $\begin{array}{l}0 . \overline{0181} \\
0 . \overline{0222} \\
0.05 \\
0.0332\end{array}$ & $\begin{array}{l}36 \\
36 \\
35 \\
32 \\
29 \\
21\end{array}$ & $\begin{array}{l}-1 \\
3 \\
3 \\
8 \\
8\end{array}$ & $\begin{array}{l}-\overline{0} \\
0.027 \\
0.085 \\
0.093 \\
0.275 \\
0.38\end{array}$ & $\begin{array}{l}\quad \overline{0.0027} \\
0.0085 \\
0.0186 \\
0.055 \\
0.076\end{array}$ & $\begin{array}{l}27 \\
27 \\
27 \\
26 \\
24 \\
21\end{array}$ & $\begin{array}{r}- \\
1 \\
2 \\
3 \\
10\end{array}$ & $\begin{array}{l}\overline{ } \\
\overline{0} .037 \\
0.076 \\
0.125 \\
0.476\end{array}$ & $\begin{array}{l}\quad \overline{-} \\
0.0037 \\
0.0152 \\
0.025 \\
0.0952\end{array}$ & $\begin{array}{l}74 \\
74 \\
71 \\
67 \\
61 \\
48\end{array}$ & $\begin{array}{r}\overline{3} \\
4 \\
6 \\
13 \\
19\end{array}$ & $\begin{array}{l}0.04 \\
0.056 \\
0.089 \\
0.213 \\
0.395\end{array}$ & $\begin{array}{l}0 . \overline{004} \\
0.0056 \\
0.0178 \\
0.0426 \\
0.079\end{array}$ \\
\hline
\end{tabular}

TABLE C

RATES OF CHANGE TO LIGHTER WORK OF MEN AGED

70-79 YEARS : FOUNDRY AND COAL-MINE DATA

COMBINED

\begin{tabular}{c|c|c|c|c}
\hline $\begin{array}{c}\text { Age Period } \\
\mathrm{x}\end{array}$ & $\mathrm{n}$ & $\mathrm{m}$ & $\mathrm{r}$ & \multicolumn{1}{c}{$\mathrm{c}$} \\
\hline $20-29$ & 24 & - & $\overline{1}$ & $\overline{0}$ \\
$30-39$ & 24 & 1 & $0 \cdot 042$ & 0.0042 \\
$40-49$ & 23 & 1 & $0 \cdot 044$ & 0.0044 \\
$50-54$ & 22 & 2 & $0 \cdot 09$ & 0.018 \\
$55-59$ & 20 & 5 & $0 \cdot 25$ & 0.05 \\
$60-64$ & 15 & 3 & $0 \cdot 20$ & 0.04 \\
$65-69$ & 12 & 4 & $0 \cdot 333$ & 0.0666 \\
\hline
\end{tabular}

